\title{
Trendy versus Appropriate Language Use: The Position of Standard English in Formal Written and Spoken Communication among Undergraduates of Selected Universities in Abuja
}

\author{
Martha Nguemo Terna-Abah ${ }^{1}$ \\ ${ }^{1}$ Department of English Language and Communication Studies, Faculty of Arts and Social Sciences, Nile \\ University of Nigeria, Abuja, Nigeria \\ Correspondence: Martha Nguemo Terna-Abah, Nile University of Nigeria, Abuja, Nigeria. \\ Email: martha@nileuniversity.edu.ng
}

Doi: $10.23918 /$ ijsses.v8i2p108

\begin{abstract}
This paper examines the prevalence of nonstandard English usage in formal communication among selected undergraduates and its implication on the Standard English. The paper begins by looking at the choice of appropriate English language variety suitable for any given context as one of the yardsticks for determining one's competence in English language. It thereafter establishes the fact that younger English language users are increasingly finding it difficult to draw boundaries between when to use nonstandard English varieties which are popular among them and when to use the standard varieties considered appropriate in formal communication. Data was collected from students' spoken and written communication. Using Fishman's Domain and Topics as its theoretical framework, the paper analysed the data obtained against the contexts within which they were used and established that their use in those contexts was inappropriate. The work was able to also establish that these usages pose a threat to the Standard English and formal communication as they lead to ambiguity and loss of meaning which make comprehension difficult for the targeted audience. After discussing the way forward, the paper concludes by reiterating the fact that although the emerging variety of English prevalent among the youths is rich and interesting, its use in formal communication remains largely inappropriate.
\end{abstract}

Keywords: Nonstandard English, Standard English, Social Context, Domain and Topics

\section{Introduction}

One of the major yardsticks for determining one's level of proficiency in the English language is partly, the ability to adhere to the rules governing the use of the language particularly with regards to how one selects its varieties suited for any given social context. Most sociolinguists are unanimous on the central role that context plays in determining the choice and use of an English language variety. Schneider (2011) while commenting on the appropriateness of the Standard English variety's usage in formal contexts for instance opines that, "'the Standard English is the variety of language considered by its speakers to be 'the most appropriate in formal and educational contexts"' (p. 16).

Received: April 21, 2021

Accepted: June 12, 2021

Terna-Abah, M.N. (2021). Trendy versus Appropriate Language Use: The Position of Standard English in Formal Written and Spoken Communication among Undergraduates of Selected Universities in Abuja. International Journal of Social Sciences \& Educational Studies, 8(2), 108-117. 
Unfortunately, with the advent of especially Smart Phones and by extension the social media as well as pop culture, it is becoming increasingly difficult for younger English language users who are so exposed to nonstandard varieties of the English language to confine its use to informal contexts. The prevalent use of nonstandard forms considered trendy by such language users in general and particularly the target population for this study has a lot of implications on the Standard English language and formal communication. It is against the above background that this study seeks to find out what these usages are and the implications that they have on the Standard English language.

\section{A Brief Review of Relevant Literature}

\subsection{Standard/Formal English}

According to Jowitt (2004, p.15), formal or Standard English is.

a variety in which other varieties are evaluated; there is an expectation that other varieties will enter into conformity with this variety and that the lack of uniformity displayed among the varieties will be removed.

Jowitt's views are corroborated by Schneider (2011, p.15) who in his definition of Standard English opines that, "we are taught that there is a "proper English" or "Standard English" which is correct, "good," and more or less fixed, somewhat like mathematics".

Like Jowitt and Schneider, Crystal (2008, p.450) though from a sociolinguistic perspective sees Standard English as,

the variety of English used as a communicative norm throughout the English-speaking world cutting across regional differences, providing a unified means of communication and thus an institutionalized norm which can be used in the mass media, in teaching the language to foreigners, and so on.

The definitions examined above see the Standard English variety as being very formal, the most widely recognized, intelligible and devoid of mistakes and errors hence the most appropriate in formal communication. This assertion is summed up by Schneider (2011, p.16) thus, "the Standard English is the variety of language considered by its speakers to be 'the most appropriate in formal and educational contexts."

\subsection{Nonstandard/Informal English}

According to Corder and Ruszkiweicz (1979, p.10), a language can be called nonstandard 'if its spelling is inconsistent, its punctuation idiosyncratic and its usage not widely accepted'. They go further to define the nonstandard English as,

most often defined by its vocabulary, its sounds or its grammatical construction and its appropriateness in discussions of informal or humorous situations and activities such as sports...nonstandard English is the same with informal English ...it is marked as colloquial in dictionaries and most of those marked as slang. 
In the same vein, Crystal (2008, p.195) defines nonstandard English as that 'linguistic form which does not conform to the norms"' (450). He adds that "it is highly informal, very loosely structured, involving a high level of colloquial expression, and often departing from standard norms (e.g., by using slang, regionalisms, neologisms, and code-mixing)'”.

From the foregoing, the nonstandard or informal English is not suitable for formal communication based on its limited spread, inconsistences in spelling, punctuation among others. These views are corroborated by Alo (2004, p.16) who also maintains that the nonstandard English is 'that which may be used by people who are intimate (e.g., friends, husband and wife) and allows such devices as direct references, interjections, abbreviations and so on'.

\section{The Role of Social Context in Determining the Choice of English Language Variety}

Social context plays a vital role in determining which variety of language to be used in any given context. According to Trudgil (1974, p.103) "language varies not only according to the social characteristics of the speaker (such as social class, ethnic group, age and sex) but also according to the social context in which a user finds himself'. He goes on to add that,

certain subject matters under discussion are likely to produce a more formal variety than others. The physical setting and occasion of the language activity like academic lectures and ceremonial occasions are more likely to select relatively formal language than publichouse arguments or family breakfasts... speech between individuals of unequal rank (due to status in an organization, social class, age, or some other factors) is likely to be less relaxed and more formal than that between equals. Thus, in most, if not all linguistic communities, differences in social context (broadly defined to include the hearer, the subject matter and the medium as well as the situation) lead to the use of different styles. (Trudgil 1974, pp.103-110).

In the same vein, Alo (2004, p.77) who corroborates Trudgil's submisssion opines that,

the nonstandard English is appropriate for communication among people who are intimate such as friends, husbands, and wife while the nonstandard English is appropriate for formal contexts such as lectures, public addresses, business reports, formal discourse or when we meet people for the first time and are uncertain as to how to respond to them.

From the foregoing, it can be seen that both the standard and nonstandard varieties of the English language have certain contexts where their use is deemed appropriate and others where it is not. It therefore follows that formal context as outlined by Trudgil and Alo above would call for the use of the standard English while the nonstandard English would be the right choice for informal contexts even though this was not the case with the subjects of this study as shown by the data obtained for this study.

\section{Theoretical Framework}

The model adopted for this work is Fishman's 'Domain and Topics" model. Also known as 'domain analysis,' this model was postulated by Fishman in 1972. According to Fishman (1972, p.587) domain is, 
a socio-cultural construct abstracted from topics of communication, relationships between communicators and locales of communication in accordance with the institutions of a society and the spheres of activity of a speech community.

Consequently, Fishman attempts to correlate physical setting and social context with language choice by asking the question "who speaks what language, to whom, when and why by using the following parameters: topic, interlocutor and spatial-temporal setting or domains." By domain, Fishman means "institutional contexts" in which one language variety is more likely to be appropriate than another. This theory would thus be used to establish the appropriateness or otherwise of the identified trendy nonstandard forms against the respective contexts within which they were used.

\section{Methodology}

Data for this paper was obtained from the spoken and written formal communication of selected undergraduates across three universities within Abuja. To do this, a lexical file was opened to collect data from students' examination scripts particularly those of Advanced English Composition, students' emails, official letters, final year projects, class presentations, formal interactions during lectures, classroom observation, interaction with students in the office, among others.

\section{Data Presentation}

The data obtained from the target group is presented in two segments. The first segment tabulates nonstandard words extracted from students' formal communication showing their meanings within the given contexts and then their Standard English equivalents and meanings while the second segment presents some of the original sentences extracted from both the spoken and written communications of the target population.

Table 1: Table showing identified nonstandard English words used in formal written and spoken communication, their meanings and formal/ Standard English equivalents

\begin{tabular}{|l|l|l|l|l|}
\hline S/No & $\begin{array}{l}\text { Trendy/Non- } \\
\text { standard } \\
\text { Word }\end{array}$ & $\begin{array}{l}\text { Meaning of Nonstandard } \\
\text { Word as Used in the } \\
\text { Given Context }\end{array}$ & $\begin{array}{l}\text { Meaning of identified } \\
\text { Words in the Standard } \\
\text { English }\end{array}$ & $\begin{array}{l}\text { Standard } \\
\text { English } \\
\text { Equivalent }\end{array}$ \\
\hline 1 & Gosh & $\begin{array}{l}\text { God! used as an } \\
\text { exclamation }\end{array}$ & nonexistent & $\begin{array}{l}\text { God! oh no! oh } \\
\text { dear! }\end{array}$ \\
\hline 2 & Drip & $\begin{array}{l}\text { having a lot of } \\
\text { money/expensive clothes }\end{array}$ & $\begin{array}{l}\text { of liquid: to fall in } \\
\text { small drops, a piece of } \\
\text { equipment that passes } \\
\text { liquid, food, medicines }\end{array}$ & $\begin{array}{l}\text { flashy, } \\
\text { ostentatious, } \\
\text { having a high } \\
\text { taste }\end{array}$ \\
\hline 3 & Bread & Money & $\begin{array}{l}\text { food made from flour } \\
\text { and yeast }\end{array}$ & money \\
\hline
\end{tabular}




\begin{tabular}{|c|c|c|c|c|}
\hline 4 & Ship & $\begin{array}{l}\text { match-make/arrange } \\
\text { friendships, romantic } \\
\text { relationships or even } \\
\text { marriage derived from } \\
\text { friendship. }\end{array}$ & $\begin{array}{l}\text { large boat for } \\
\text { transporting people or } \\
\text { goods by sea. } \\
\text { to transport people or } \\
\text { goods }\end{array}$ & match-make \\
\hline 5 & lit & $\begin{array}{l}\text { exciting, excellent, cute, } \\
\text { amazing }\end{array}$ & $\begin{array}{l}\text { past participle form of } \\
\text { light }\end{array}$ & $\begin{array}{l}\text { cute, exciting, } \\
\text { attractive }\end{array}$ \\
\hline 6 & Squad & $\begin{array}{l}\text { group of friends that stay } \\
\text { together always }\end{array}$ & $\begin{array}{l}\text { a small, organized } \\
\text { group of military } \\
\text { personnel especially a } \\
\text { tactical unit that can } \\
\text { easily be directed in the } \\
\text { field }\end{array}$ & close friends \\
\hline 7 & Tool & $\begin{array}{l}\text { someone who is stupid, } \\
\text { obnoxious, rude }\end{array}$ & $\begin{array}{l}\text { hand instruments like } \\
\text { hammer, screwdriver } \\
\text { etc }\end{array}$ & $\begin{array}{l}\text { obnoxious, } \\
\text { rude, stupid } \\
\text { person }\end{array}$ \\
\hline 8 & $\begin{array}{l}\text { ghost, } \\
\text { ghosting, } \\
\text { ghosted }\end{array}$ & $\begin{array}{l}\text { to avoid someone or to } \\
\text { abruptly cut off all } \\
\text { contact with someone by } \\
\text { no longer accepting or } \\
\text { responding to texts }\end{array}$ & $\begin{array}{l}\text { an apparition of a dead } \\
\text { person which is } \\
\text { believed to appear or } \\
\text { become manifest to the } \\
\text { living typically as a } \\
\text { nebulous image }\end{array}$ & $\begin{array}{l}\text { avoid, jilt, } \\
\text { reject }\end{array}$ \\
\hline 9 & Snatched & stunning, good, gorgeous & $\begin{array}{l}\text { simple past/past } \\
\text { participle form of } \\
\text { snatch. to take } \\
\text { something quickly and } \\
\text { often forcefully or } \\
\text { roughly }\end{array}$ & $\begin{array}{l}\text { gorgeous, } \\
\text { stunning, } \\
\text { magnificent }\end{array}$ \\
\hline 10 & bin or bn & past participle form of be & $\begin{array}{l}\text { a receptacle for } \\
\text { depositing rubbish }\end{array}$ & \\
\hline 11 & Yeah & Yes & Nonexistent & yes \\
\hline 12 & Fire & $\begin{array}{l}\text { hot, trendy, amazing, } \\
\text { better than others hot, } \\
\text { trendy, amazing, better } \\
\text { than others }\end{array}$ & $\begin{array}{l}\text { the smoke, light and } \\
\text { heat that are produced } \\
\text { when something heats }\end{array}$ & $\begin{array}{l}\text { cute, stunning, } \\
\text { gorgeous }\end{array}$ \\
\hline 13 & Ystdy & Yesterday & Nonexistent & yesterday \\
\hline 14 & Cool & fine, okay & $\begin{array}{l}\text { fairly cold, not hot or } \\
\text { warm }\end{array}$ & fine, okay \\
\hline 15 & Dough & Money & $\begin{array}{l}\text { a thick, malleable } \\
\text { mixture of flour and } \\
\text { liquid used for baking } \\
\text { into bread or pastry }\end{array}$ & money \\
\hline
\end{tabular}




\begin{tabular}{|c|c|c|c|c|}
\hline 16 & (good) p.m. & good evening & post-meridian & good evening \\
\hline 17 & Fire & $\begin{array}{l}\text { hot, trendy, amazing, } \\
\text { better than others hot, } \\
\text { trendy, amazing, better } \\
\text { than others }\end{array}$ & $\begin{array}{l}\text { the smoke, light and } \\
\text { heat that are produced } \\
\text { when something heats }\end{array}$ & cute, stunning \\
\hline 18 & $\mathrm{u}, \mathrm{ur}$ & you, your & Nonexistent & you and your \\
\hline 19 & Jeez! & $\begin{array}{l}\text { Jesus! used as an } \\
\text { exclamation }\end{array}$ & Nonexistent & Jesus! oh no! \\
\hline 20 & Guy & young man, man & Nonexistent & $\begin{array}{l}\text { young man, } \\
\text { gentle man }\end{array}$ \\
\hline 21 & Swag & confident, fashionable & $\begin{array}{l}\text { (Old fashioned) stolen } \\
\text { goods }\end{array}$ & $\begin{array}{l}\text { confident, } \\
\text { elegant, well- } \\
\text { dressed }\end{array}$ \\
\hline 22 & Bae & $\begin{array}{l}\text { 'Before anyone else', } \\
\text { used to refer to a } \\
\text { boyfriend or girl friend }\end{array}$ & $\begin{array}{l}\text { nonexistent in the } \\
\text { standard English }\end{array}$ & $\begin{array}{l}\text { boyfriend or } \\
\text { girl friend }\end{array}$ \\
\hline 23 & Ice & Diamonds & frozen water & diamonds \\
\hline 24 & Salty & $\begin{array}{l}\text { bitter, angry, hostile, } \\
\text { jealous }\end{array}$ & containing a lot of salt & $\begin{array}{l}\text { bitter, angry, } \\
\text { hostile, } \\
\text { intolerant, } \\
\text { jealous }\end{array}$ \\
\hline 25 & Bestie & best friend & Nonexistent & best friend \\
\hline 26 & Dayger & to party during the day & Nonexistent & $\begin{array}{l}\text { Partying during } \\
\text { the day }\end{array}$ \\
\hline 27 & Dead & $\begin{array}{l}\text { Hysteric, laughing so } \\
\text { hard }\end{array}$ & No longer alive & hysteric \\
\hline 28 & Slay & $\begin{array}{l}\text { gorgeous, stunning, } \\
\text { excellent }\end{array}$ & $\begin{array}{l}\text { To kill somebody or } \\
\text { something in a war or } \\
\text { fight }\end{array}$ & $\begin{array}{l}\text { gorgeous, } \\
\text { stunning, } \\
\text { excellent }\end{array}$ \\
\hline 29 & Sus & Suspicious & non existent & suspicious \\
\hline 30 & Hood & Neighbourhood & $\begin{array}{l}\text { A part of a coat that } \\
\text { you can pull up to } \\
\text { cover the back and top } \\
\text { of your head. } \\
\text {-a piece of fabric put } \\
\text { over one's face or head } \\
\text { so that they cannot be } \\
\text { recognized or seen }\end{array}$ & neighbourhood \\
\hline
\end{tabular}




\begin{tabular}{|l|l|l|l|l|}
\hline 31 & Savage & $\begin{array}{l}\text { bold, not caring about the } \\
\text { consequences of one's } \\
\text { actions }\end{array}$ & $\begin{array}{l}\text { fierce, violent } \\
\text {-an offensive way of } \\
\text { referring to groups of } \\
\text { people or customs that } \\
\text { are considered to be } \\
\text { simple and are highly } \\
\text { developed }\end{array}$ & $\begin{array}{l}\text { bold, confident, } \\
\text { reckless }\end{array}$ \\
& & & \\
\hline
\end{tabular}

B. Original Sentences Obtained from Formal Written and Spoken Communication stating the exact source.

1. Good p.m ma (extracted from an official email)

2. We are cool with it. (Extracted from spoken communication)

3. Yeah, I am the person. (Extracted from spoken communication)

4. Ma, I didn't see the guy (Extracted from spoken communication)

5. She is my bestie. (Extracted from spoken communication)

6. Gosh! Please ma. (Extracted from spoken communication)

7. Jeez! (Extracted from Spoken Communication)

8. He was her bae right from secondary school. (Extracted from written communication)

9. I checked but $\boldsymbol{u}$ was not around (Extracted from written communication).

10. I am cool with it. (Extracted from spoken communication)

11. The wedding was lit. (Extracted from written communication)

12. Nobody knew she was salty until that day... (Extracted from written communication)

13. They both had swag.... (Extracted from written communication)

14. They were shipped by their fans.... (Extracted from written communication)

15. I was the one who saw you ystdy (Extracted from written communication)

16. His last performance was fire. (Extracted from written communication)

17. She slayed in a black dress that evening (Extracted from written communication)

18. He used her to chase clout... (Extracted from written communication)

\section{Discussion of the Findings}

Going by Fishman's domain and topics model, the data presented and analysed above shows that, even though the identified words may have been trendy among the target group in particular and youths in general, their usage in the context or domain under review is inappropriate. This is because, the various contexts which were very formal had to do with both examinations, official correspondences and formal verbal discourses between the lecturer and the students.

The data establishes further that nonstandard English usage is very much prevalent among the younger generation of English language users. The data has also revealed a very rich and unique communication pattern among the youths which shows potential of becoming a full-fledged language with time especially if not checked. Some of the words identified have the same spellings with Standard English words but different meanings. Examples include "'curve," 'ship", ''bread,' "'dough," "'ice,' 'drip,' among others. This has the potential of bringing about ambiguity especially in instances where their meanings cannot be easily deduced from the contexts within which they are used. There are instances where meaning 
is totally lost because of the use of certain abbreviations and contracted forms which may be common to youths but uncommon to those outside their circle. Examples include 'ystdy," "'ur," "'bn,' among others.

It has also been established that, most of these trendy vocabulary items are derived from the lyrics of the music of celebrated Hip Hop and Rhythm and Blues (R\& B) artists like Cardi B, Chris Brown, Beyonce, Jay Z, Rihanna, Lil Watne, Niki Minaj, Kanye West, Whiz Kid, Davido, Burna Boy and so on. Examples of such usages include the following: The word "drip" as used by the target population originates from Cardi B's song titled "Drip," "'ice'" as used was obtained from a song titled "Nice" by Beyonce and Jay-Z, 'savage"' was derived from Megan Thee Stallion' song titled 'Savage," 'clout' was derived from Offset and Cardi B's song titled 'Clout"'

From the data obtained and analysed, it has also been observed that nonstandard words for money, fashion and relationships appear to more commonly used than those that have to do with other aspects of life. This finding is not surprising as these are the major areas of concern for most youths. Examples include dough, bread (money), ship, ghost, curve (relationship) drip, dope, lit, fire, snatched, slay, fire (all have to do with fashion and appearance)

\section{The Implications of Informal English Choice in Formal Communication on the Standard English}

While trying not to sound alarming yet at the same time putting out the facts, I want to summit based on the findings of this paper in particular and my own general observations that the Standard English language is under threat especially among the youths for these obvious reasons:

There is that lack of interest among many youths in striving to attain a mastery in the appropriate use of the English language as more attention is paid on the acquiring the latest slangs and other forms of nonstandard English than it is spent of enhancing their standard English vocabulary and usage.

The prevalence in the use of these nonstandard forms has made it increasingly difficult for younger users of the English language to differentiate and draw boundaries between when to use the standards English forms and when to use the nonstandard English forms. Consequently, and most often too, nonstandard English is used in contexts that call for very formal English language use.

The use of nonstandard forms in formal communication has further compounded the problems of ambiguity especially in situations where the same word exists in both the standard English and nonstandard English varieties however with different meanings Examples abound from the data collected and analysed: The word 'salty' is used in standard English to mean 'too much salt' while it was used in the given context to mean 'bitter' or 'angry.' "Fire," 'lit," "snatched," "slay', were used to mean "'stunning," "gorgeous," "cute", while they mean other things in the Standard English as shown in the table above.

Another implication of the prevalent use of informal English considered trendy among youths on the Standard English is in the area of standard orthography. The generally recognized spelling system of the English language is gradually being replaced by abbreviations and other contracted forms. In some instances, single letters and numbers are used in place of words like the letter "'u" for "you" "cc" ' 2 ", 
for "to" among others. This has in addition to the arbitrariness of the English language further compounded the problem of comprehension in communication.

Loss of meaning leading to communication breakdown is another implication of these usages on the Standard English language in formal communication. Comprehension becomes nearly impossible where nonstandard words which are nonexistent in the English language or totally different meanings are used in formal communication especially in situations where the target audience happen to fall outside the circle of younger users of the language. Examples of such usages from the data obtained include: 'dayger,' dough," 'bread," "'lit," ' 'fire', among others. There is a high tendency that the Standard English variety may go into extinction if nothing is done aggressively by lovers of the variety to preserve it.

\section{The Way Forward}

Studies like this make us realise how much we have on our hands as teachers, parents, and stakeholders. It must be emphasized here that nonstandard varieties of the English language are equally very useful in meeting communicative needs of users in informal contexts however, students must know that these varieties are only appropriate in informal contexts or communication and that their ability to select appropriate varieties that suit given contexts is actually what makes them proficient users of the language to a large extent.

In order to check the indiscriminate use of informal English in formal contexts therefore, students should be encouraged at all times to improve upon their standard English vocabulary by spending more time reading relevant literatures, listening to international news broadcast television channels like CNN, BBC, Aljazeera among others instead of constantly listening to music, watching movies and chatting on social media where the use of these nonstandard forms is common and acceptable. Teachers must also not shy away from penalizing students where necessary especially through the deductions of scores under "'mechanical accuracy" and "expression", when such expressions are used. This will deter those found wanting from the continuously using such expressions.

Quizzes and debates can also be organized at intervals to expose students to the standard English variety. Where informal English is being used in the course of delivery, corrections must be made on the spot before such mistakes become fossilised. Those saddled with the responsibility of imparting knowledge must be role models themselves and avoid the use of nonstandard English varieties in formal contexts so as not to mislead those who look up to them as role models.

\section{Conclusion}

Every language variety is important and capable of meeting the communicative needs of its users. However, problems arise when a language user fails to use a variety suitable for the context within which it is being used irrespective of how popular such a variety is. The emerging youth language characterized by novel slang expressions, coinages, pidgins among others, although popular among its young users, is considered inappropriate when used in formal communication instead of the Standard English variety. Youths must therefore ensure that boundaries are drawn and respected when communicating formally so as to avoid a breakdown in communication. 


\section{References}

Alo, M.A. (2004). Context and language variations: The EL2 example in L. Oyeleye (Ed), Language and discourse in society. (pp. 73-82) Ibadan: Hope publishers

Corder, J., \& Ruszkiewicsz, J. (1979). Handbook of current English. London: Scott Foresman,

Crystal D. (2008). A dictionary of linguistics and phonetics. Sixth Edition Oxford: Blackwell Publishing Limited.

Fishman, J.R. (1972). Language in sociocultural change. California: Stanford University Press.

Jowitt, D. (2007). Standard Nigerian English: A Re-Examination. Journal of the Nigeria English Studies Association. Ikot Ekpene: NESA and DEVCONSORT publishers (pp. 2-3).

Schneider, E. (2011). English around the World: An Introduction. Cambridge: Cambridge University Press.

Trudgil, P. (1974). Sociolinguistics: An introduction to language and society. England: Penguin Book Ltd. 